\title{
Trends in inflammatory bowel disease therapy: A meta-analytic approach
}

\author{
Gregory W Whiting Ba, Joseph LAU mD, BRUCE KuPELnick BA, ThOMAS C Chalmers mD
}

\begin{abstract}
GW Whiting, J LAU, B KuPELnick, TC CHALmers. Trends in inflammatory bowel disease therapy: A meta-analytic approach. Can J Gastroenterol $1995 ; 9(7): 405-411$.
\end{abstract}

OBJECTIVE: To illustrate the current meta-analytic approach to extracting clinically useful information from the glut of randomized controlled trials (RCTs) of the treatment of acute attacks of Crohn's disease.

PROCEDURE: Acceptable RCTs were classified in a matrical format so that the feasibility of a meta-analysis of each treatment could be quickly determined. Each potential inclusion was then photocopied after blinding the source and outcome to minimize bias by the investigators.

RESULTS AND CONCLUSIONS: The search was started in 1990, when a previous meta-analysis was completed. Over 100 citations in MEDLINE contained 21 RCTs of the treatment of acute attacks of Crohn's disease, and 11 more were culled from the references of recent papers. The meta-analysis most indicated by the matrix was a comparison of several different immunosuppressive regimens with a placebo. The previously demonstrated statistical significance was confirmed and the point made that it is no longer justified to compare any new treatments with a placebo. Cumulative meta-analysis, the process of performing a new analysis every time a new trial is published, revealed the importance of employing both random and fixed effect models when heterogeneity of treatment results is appreciable, as in this case.

Key Words: Crohn's disease, Immunosuppression, Meta-analysis, Therapy

Tendances du traitement de la maladie inflammatoire de l'intestin : approche méta-analytique

OBJECTIFS : Illustrer l'approche méta-analytique actuelle d'extraction des données cliniquement pertinentes à partir de l'amas d'essais contrôlés randomisés (ECR) qui ont porté sur le traitement des poussées aiguës de maladie de Crohn.

PROCÉDURES : Les ECR acceptables ont été classés sous forme de matrice pour que la faisabilité de la méta-analyse puisse être rapidement déterminée pour chaque traitement. Chaque essai potentiel a ensuite été photocopié après que la source et le résultat en aient été biffés, afin de minimiser tout risque de biais de la part des investigateurs.

voir page suivante

MetaWorks, Inc; and the Division of Clinical Care Research, New England Medical Center, Boston, Massachusetts, USA

Correspondence and reprints: Dr Thomas C Chalmers, MetaWorks, Inc, 470 Atlantic Avenue, Boston, MA 02210, USA. Telephone 617-368-3575, fax 617-368-3591

This paper was presented at the Trends in Inflammatory Bowel Disease Therapy meeting, April 6 to 9, 1994, held in Victoria, British Columbia. This paper has also been published in Sutherland LR, et al, eds. Inflammatory Bowel Disease: Basic Research, Clinical Implications and Trends in Therapy. Boston, Dordrecht and London: Kluwer Academic Publishers, 1994
$M$ ETA-ANALYSIS IS MORE THAN A statistical technique for pooling data from multiple primary research reports. It is a wholly new and precise discipline for gathering and transferring the results of primary research projects into a valid and understandable format so that they can be applied to patient care by physicians and those who set medical policy.

Crohn's disease is a perfect example of the serious problem physicians and health care policy-makers face when trying to keep up with the potential impact of research on medical practice. In a disease of unknown etiology, especially one with acute and chronic manifestations, there is bound to be an increasing explosion of important clinical trials. Publication of review articles written by clinical experts has been the classical way of keeping everybody informed. That route has been increasingly found to be flawed because of evidence of nonthorough literature searches and of bias in the selection and interpretation of published trials in many fields; there is no reason to think that Crohn's disease meta-analysis is any different. Compared with those who prepare meta-analysis, the writer of reviews and textbook chapters does not present all evidence on which opinions and recommendations are based.

The purpose of this paper is to illustrate the application of all aspects of the technique of meta-analysis to the pharmacological treatment of acute attacks of Crohn's disease, a common clinical problem requiring frequent updates of therapeutic advances. 
RÉSULTATS ET CONCLUSIONS : La recherche a commencé en 1990 alors qu'une méta-analyse précédente arrivait à terme. Plus de 100 citations tirées de MEDLINE renfermaient $21 \mathrm{ECR}$ sur le traitement des poussées aiguës de maladie de Crohn et 11 autres provenaient de la bibliographie d'articles récents. La métaanalyse mise en évidence par la matrice était une comparaison de différents schémas immunosuppresseurs avec placebo. La portée statistique précédemment démontrée a été confirmée et il n'est plus justifié de comparer les nouveaux traitements avec placebo. La méta-analyse cumulative, le processus d'analyse exigé pour chaque nouvel essai publié, a révélé l'importance d'employer des modèles d'essais randomisés et fixes lorsque l'hétérogénéité des résultats des traitements est appréciable, comme c'est le cas ici.

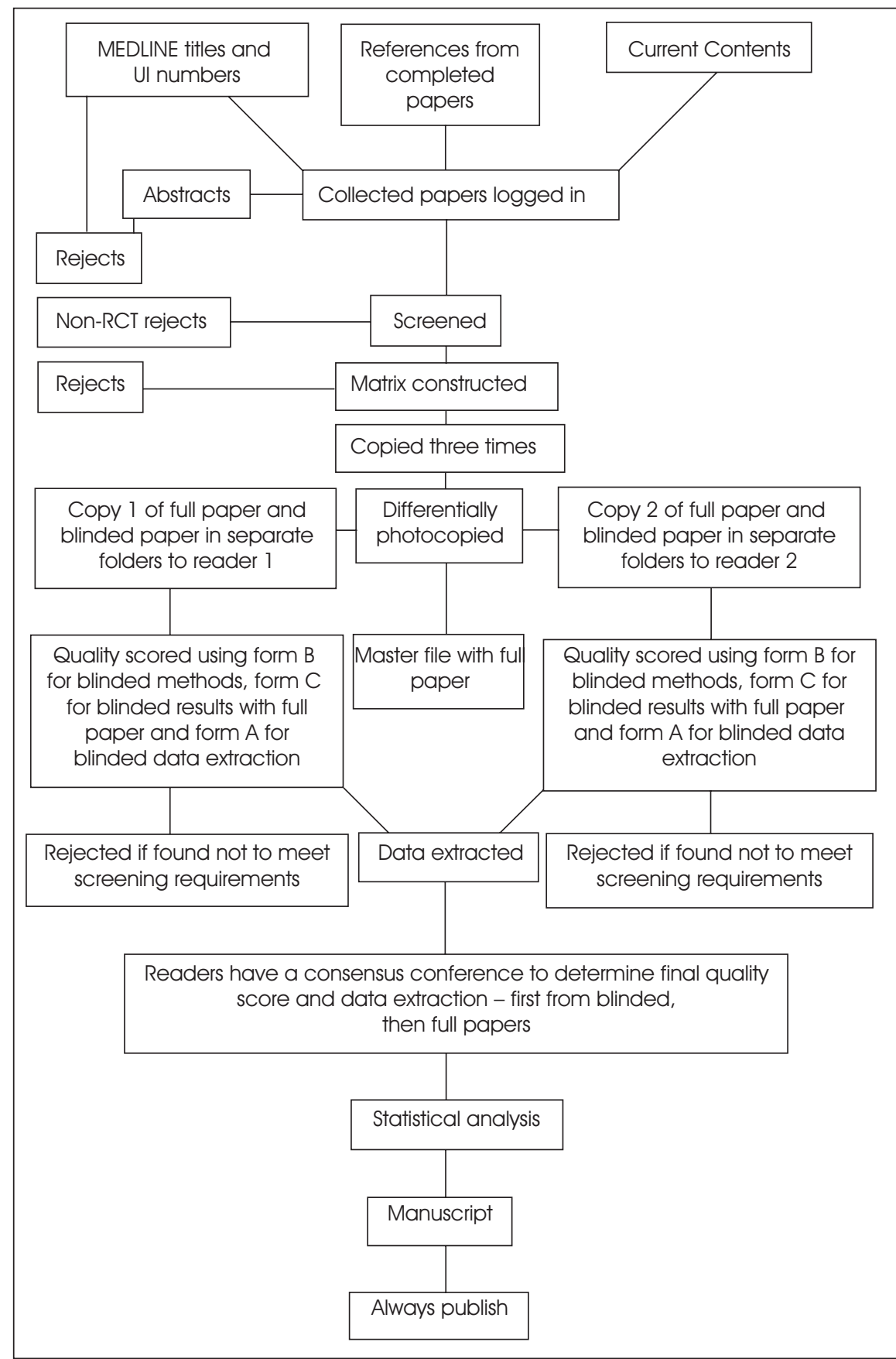

Figure 1) Diagram of a meta-analytic process designed to ensure that all relevant published articles are included, that bias is minimized by blinding information that might influence selection of papers and extraction of data, and that errors are minimized by duplicate performance. RCT Randomized controlled trial; UI Unique identifier. Reproduced with permission from reference 1

\section{CRITERIA FOR A GOOD META-ANALYSIS}

If meta-analyses are to be reliable conduits of original medical information they must be reliably performed. Calling something a meta-analysis or 'structured' review calls into play certain methodological rules, which if neglected could and should lead to rejection by editors or peer reviewers of the whole effort. This protection of the reader only works if there is reasonable agreement about the characteristics of an acceptable meta-analysis. The search for original data must be as complete as possible, bias must be minimized by blinding papers before decisions are made by the investigators and all steps must be carried out in duplicate to minimize errors. These initial steps are illustrated schematically in Figure 1. Once a subject has been selected, references are sought in review articles and recent randomized controlled trials (RCTs). Medical subject heading terms and key words for a MEDLINE search are gleaned from a recovery of the first articles in MEDLINE. However it has been demonstrated at least seven times (1) that a MEDLINE search for clinical trials only recovers about $50 \%$ of the articles found by other means (two-thirds in this case). Most of the clinical trials found elsewhere are actually in MEDLINE when an author search is carried out, so the defect lies in subject cataloguing.

The conscientious clinical investigator will also have been perusing Current Contents each week for inflammatory disease trials. As for other diseases, there are also special publications of bibliographies and abstracts; in this case, Trends in Inflammatory Bowel Disease Therapy, published in June 1993 (2).

Once a number of candidate papers have been logged in, a preliminary screening is carried out and the review articles and uncontrolled trials rejected. A matrix of comparisons is then constructed and a decision is made about which meta-analyses to undertake. A technician blots out all information in the selected papers relative to the sources, dates and therapeutic regimens of each trial before photocopying ('differential photocopying'). 
The sources and dates are left blank while the therapeutic regimen is encoded A or B, or X or Y. One copy of this blinded paper is placed in the master file with the original and one copy is given to each investigator, along with an unaltered copy to be consulted when all questions that could be answered from the blinded copy are answered. Pertinent data are extracted by each investigator, and quality questionnaires are filled using only the 'Methods' and 'Results' sections (3). A consensus conference is then held to iron out the differences, which typically occur 15 to $21 \%$ of the time. There are occasional exceptions to the above process, as when a few papers are well known to all and others are added late, but an attempt is made to do each study properly. Because those familiar with the field will easily recognize a few papers, an attempt is made in each instance to include a methodologist or student as one of the investigators, in addition to the expert in the field.

After the consensus conference, tables of results are constructed in a standard format and the statistical analyses carried out by more than one method.

Unfortunately there is no quantitative system for scoring quality to reflect that bias might distort the results, so the confidence intervals are not weighted by the quality scores. Instead the included RCTs are listed in order of descending quality score so that the investigators or readers can do their own sensitivity analyses by omitting the worst papers to see whether the results are inordinately influenced by the worst research. Other sensitivity analyses can then be carried out, such as removing studies with outlying treatments or unusual patients. Subgroup analyses can be done at this stage, but with great caution to avoid the accusation of data-dredging.

\section{CUMULATIVE META-ANALYSIS: AN EXCITING INNOVATION}

If a new meta-analysis is performed every time a new study is published or found, critical new information is presented. As an example, a standard format meta-analysis of RCTs comparing

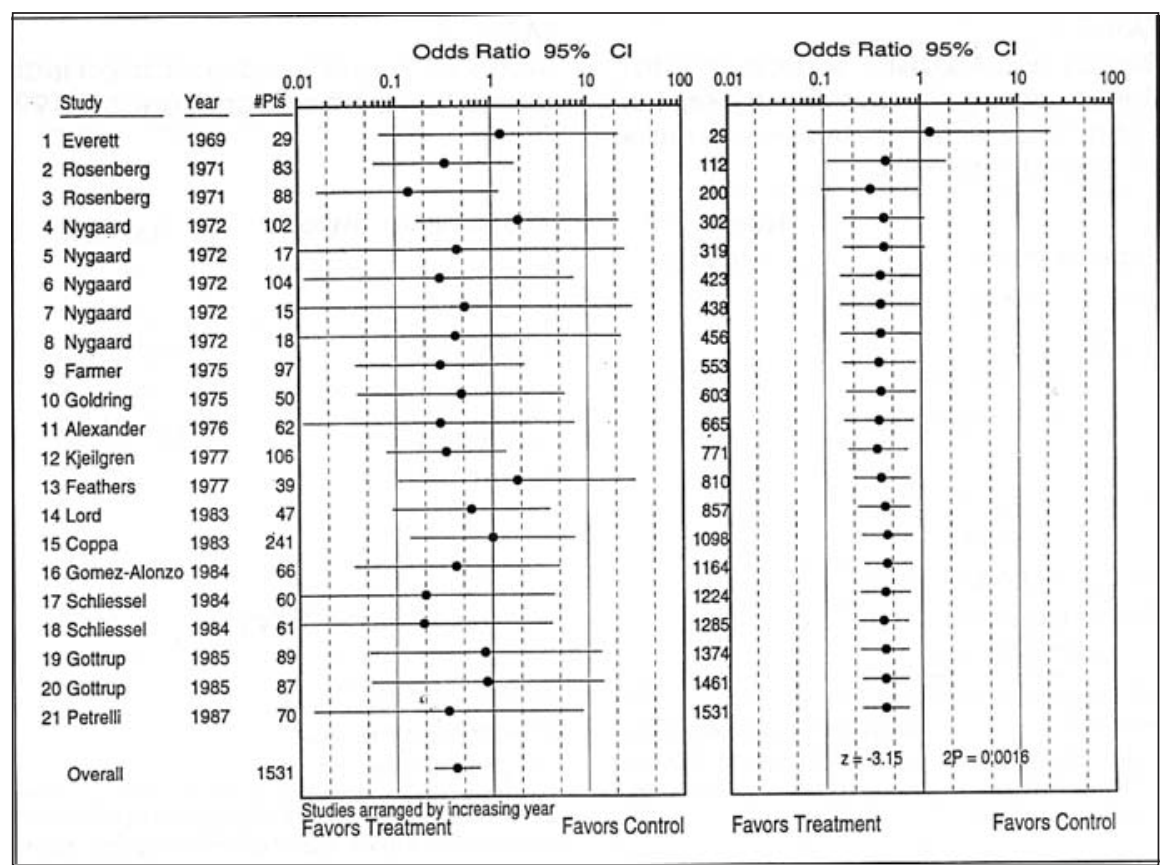

Figure 2) A meta-analytic approach - fixed effects model (Mantel-Haenszel) - to randomized controlled trials of the efficacy of perioperative antibiotics in reducing the operative death rates from surgery for colon cancer. The standard chart on the left reveals that none of the individual trials was statistically significant and the cumulative meta-analysis on the right reveals that statistical significance was achieved by 1975. In this case, heterogeneity is not significant, so the random and fixed effects models give the same results. OOdds ratio: under 1.0 favours the antibiotics. The horizontal lines are the $95 \%$ CIs around each ratio. The end-point is perioperative death. Pts Patients. References listed in this figure can be obtained in full from the corresponding author

TABLE 1

Therapy comparison matrix of randomized controlled trials of therapy for acute attacks of Crohn's disease

\begin{tabular}{|c|c|c|c|c|c|c|}
\hline \multirow[b]{2}{*}{ Experimental therapy } & \multicolumn{6}{|c|}{ Comparison therapy } \\
\hline & $\begin{array}{c}\text { A } \\
\text { Placebo }\end{array}$ & $\begin{array}{c}\text { B } \\
\text { Sulfasalazine }\end{array}$ & $\begin{array}{c}\text { C } \\
\text { Steroids }\end{array}$ & $\begin{array}{l}\text { D } \\
\text { Diet }\end{array}$ & $\begin{array}{c}\text { E } \\
\text { Other }\end{array}$ & $\begin{array}{c}\mathrm{F} \\
\text { Total }\end{array}$ \\
\hline 1. Immunosuppression & $\begin{array}{c}26 ?, 72++, 42+ \\
12+, 15+, 42++ \\
134 ?\end{array}$ & & $3 ?$ & & $\begin{array}{c}37++ \\
36 ?\end{array}$ & 10 \\
\hline 2. T cell stimulants & $33+, 9 ?, 19 ?, 21 ?$ & & & & & 4 \\
\hline 3. Sulfasalazine & $26++, 54++$ & & & & $\begin{array}{l}42- \\
23 ?\end{array}$ & 4 \\
\hline 4. 5-ASA & $12 ?, 67+$ & $30+, 23 ?$ & & & & 4 \\
\hline 5. Antibiotics & $\begin{array}{c}20+, 100++ \\
52++, 7 ?\end{array}$ & & & & $\begin{array}{l}72+ \\
52 ?\end{array}$ & 6 \\
\hline 6. Steroids & $\begin{array}{c}47++, 38++ \\
85++\end{array}$ & $38+$ & & & $38+$ & 5 \\
\hline 7. Diet & $36++$ & & $\begin{array}{c}6+ \\
7+, 9 ?\end{array}$ & $\begin{array}{c}19 ? \\
10++ \\
36 ? \\
16 ? \\
28+ \\
20++\end{array}$ & & 10 \\
\hline 8. Combination & $\begin{array}{c}56++, 20+ \\
163++\end{array}$ & & $163-$ & $21++$ & $72++$ & 6 \\
\hline 9. Other & $\begin{array}{c}55 ?, 18 ?, 29 ? \\
199+, 21+, 16 ? \\
18 ?\end{array}$ & & $\begin{array}{c}80++ \\
22 ?\end{array}$ & & & 9 \\
\hline 10. Totals & 33 & 3 & 7 & 7 & 8 & 58 \\
\hline
\end{tabular}

Numbers in cells refer to the number of subjects in a specific trial. + +Statistically significant in favour of experimental therapy; + Trend in favour of experimental therapy; ?No clinically interesting difference; -Trend in favour of control therapy. 5-ASA Aminosalicylic acid. Based on reference 5 
TABLE 2

Results of a MEDLINE search for citations related to the treatment of Crohn's disease between January 1990 and April 1994

\begin{tabular}{lc}
\hline Type of study & $\begin{array}{c}\text { Number of ci- } \\
\text { tations }\end{array}$ \\
\hline Review articles & 22 \\
RCTs & $21\left(11^{\star}\right)$ \\
$\quad$ Acute treatment & 12 \\
$\quad$ Maintaining remission & 33 \\
$\quad$ Total & 7 \\
Nonrandomized and & \\
$\quad$ uncontrolled & 1 \\
Meta-analysis of RCTs & 96 \\
Total clinical trial citations & \\
\hline
\end{tabular}

*Randomized controlled trials (RCTs) of acute treatment are expanded by 11 additional ones culled from the reference lists of recent publications. A full list of the combined 32 trials appears in Appendix 1
TABLE 3

Matrix of randomized controlled trials of treatment of acute attacks of Crohn's disease published from January 1990 to March 1994

\begin{tabular}{|c|c|c|c|c|c|}
\hline \multirow[b]{2}{*}{ Experimental therapy } & \multicolumn{5}{|c|}{ Comparison therapy } \\
\hline & $\begin{array}{c}\text { A } \\
\text { Placebo }\end{array}$ & $\begin{array}{c}\text { B } \\
\text { Sulfasalazine }\end{array}$ & $\begin{array}{c}\text { C } \\
\text { Steroids }\end{array}$ & $\begin{array}{l}\text { D } \\
\text { Diet }\end{array}$ & $\begin{array}{c}\mathrm{E} \\
\text { Other }\end{array}$ \\
\hline 1. Immunosuppression & $71++, 28+$ & & & & \\
\hline 2. Sulfasalazine & $26++$ & & & & \\
\hline 3. 5-ASA & $14++, 67+$ & & $55-$ & & \\
\hline 4. Metronidazole & $56++$ & $78 ?$ & & & \\
\hline 5. Steroids & $310++, 84 ?$ & & $96 ?, 54+$ & $78++, 21 ?$ & $37 ?$ \\
\hline 6. Diet & & & $\begin{array}{l}32 ?, 42 ? \\
29 ?, 15 ? \\
24 ?, 19 ?\end{array}$ & $\begin{array}{c}14-, 30++ \\
51 ?, 28+ \\
24 ?, 30 ?\end{array}$ & $107-$ \\
\hline 7. Combination therapy & & & $\begin{array}{c}49+, 18+ \\
42++\end{array}$ & $17+$ & \\
\hline 8. Mesalamine & & $34 ?$ & & & \\
\hline $\begin{array}{l}\text { 9. Sulfasalazine and } \\
\text { prednisone }\end{array}$ & & $60+$ & & & \\
\hline
\end{tabular}

Cells contain number of patients in each randomized controlled trial and results of major end-point chosen by author. Numbers plotted are comparisons, not individual papers, due to some papers comparing more than two treatments. + +Statistically significant in favour of experimental therapy; + Trend in favour of experimental therapy; ?No clinically meaningful difference; -Statistically significant in favour of control therapy. 5-ASA Aminosalicylic acid

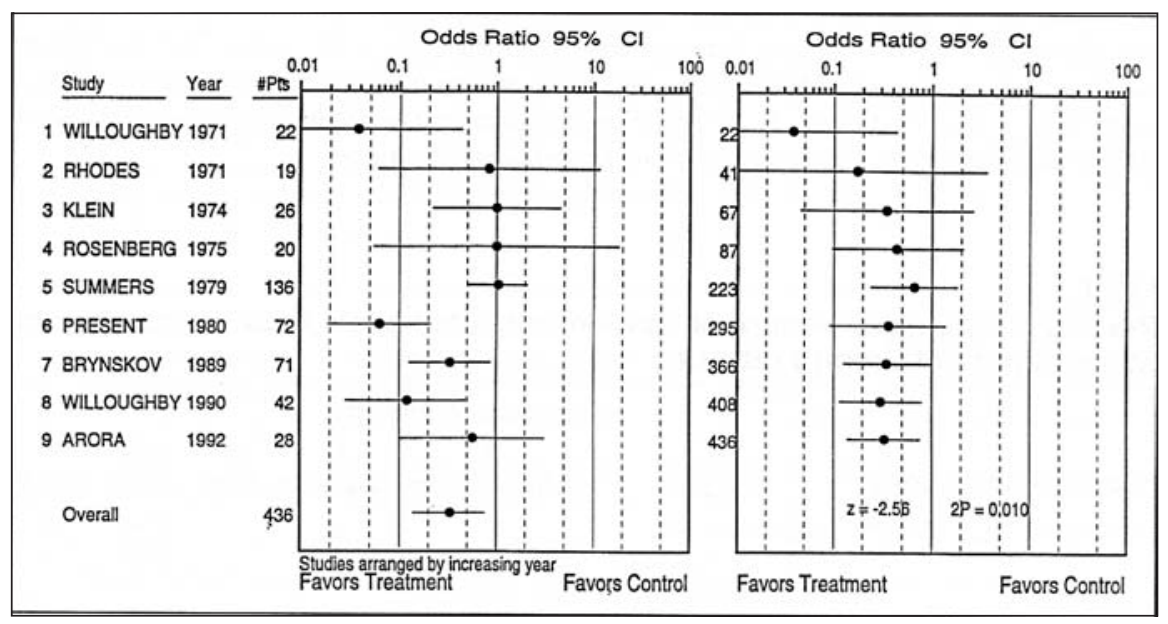

Figure 3) Random effects model (DerSimonian and Laird) showing nine randomized controlled trials of immunosuppressive therapy versus placebo for acute attacks of Crohn's disease. Results are expressed as odds ratio; experimental treatment was better than placebo when the odds ratio was less than one. Studies ordered by year of publication: standard on left and cumulative on right. Odds ratio: under 1.0 favours the immunosuppressive therapy. The horizontal lines are the $95 \% \mathrm{CIs}$ around each ratio. The end-point is clinical improvement (response rates). References listed in this figure can be obtained in full from the corresponding author. Pts Patients

perioperative antibiotics with placebo or no antibiotics in patients undergoing colorectal surgery, usually for cancer of the colon, is presented in Figure 2. Although most studies favoured the antibiotics, no study, by itself, was statistically significant. The trials also reported postoperative infection rates, in which control rates were higher and differences more often significant. How- ever, by the time 200 patients had been randomized in 1971, the differences were statistically significant, and although fluctuating in degree, the confidence intervals never crossed the unity line in the ensuing 20 years. The final illustrative $\mathrm{Z}$ and $\mathrm{P}$ values were highly significant $(2 \mathrm{P}=0.0016)$ in 1987 when the last study in this series was reported. The term 'illustrative $\mathrm{P}$ ' value is used because we have not corrected the critical $P$ value with each calculation, as some strict frequentist biostatisticians would have us do. Cumulative meta-analysis has brought to the forefront the importance of prior clinical trials in planning and stopping clinical trials. A Bayesian approach (4) seems more appropriate when dealing with a vast array of published RCTs.

\section{CROHN'S DISEASE TREATMENT AND THE NEED TO FIND EFFICIENT WAYS TO DEAL WITH RCT GLUT}

Three years ago we developed a matrical approach to the large number of available clinical trials of drugs and diet for the treatment of acute attacks of Crohn's disease for the Online Journal of Current Clinical Trials (5). The different drugs and diets considered by the authors of each RCT to be the experimental approach were placed in the rows, and the control treatments of each RCT were the columns. Into the appropriate cells were placed each study, identified by the number of patients randomized and a code for the outcome chosen by the authors as the principal one (Table 1). This process enabled the author and the reader to keep close track of the papers appearing in each cell so that the need for meta- 
analysis could be determined. For instance, a pooling of the trials of an immunosuppressant drug summarized in cell A1 was clearly indicated and was carried out (5). The success rate of the combined different immunosuppressant drugs in short term studies of varying duration was significantly better than the success rate of placebo. Cells $\mathrm{A} 2$ and $\mathrm{A} 4$ bear watching, and $\mathrm{A} 3$ and A5 appear to be statistically significant but could be checked with a metaanalysis. Cells under columns B to E are comparisons of one active treatment with another, and because of a lower failure rate among controls will require many more studies before metaanalysis is indicated. The diet studies are going to require individual analysis because most are studying different modifications. Use of the proposed matrical format facilitates a quick survey of the randomized controlled trial situation with regard to the nonsurgical treatment of acute attacks of Crohn's disease.

In 1994, four years after completion of the previous literature search, it was time for a repeat, and one was carried out for the Trends in Inflammatory Bowel Disease Therapy meeting held in Victoria, British Columbia in April 1994. Table 2 presents the results of the literature search. Ninety-six clinical trial citations were found by a MEDLINE search, $22 \%$ of which were RCTs of acute treatments. Search of published references and other databases revealed 11 more RCTs, an additional one-third.

A matrix of the RCTs published from January 1990 to March 1994 is presented in Table 3. An updated metaanalysis that includes the two new trials of an immunosuppressant versus placebo is presented in Figures 3 to 6. It is apparent that the additional trials did not need to be undertaken to establish that short term treatment was effective. It may be argued, and indeed it probably was, that additional trials were necessary to determine duration of optimal therapy, drug regimen or span of side effects, which were not apparent from the few completed studies. Once the overall question is answered it should no longer be ethical to assign new pa-

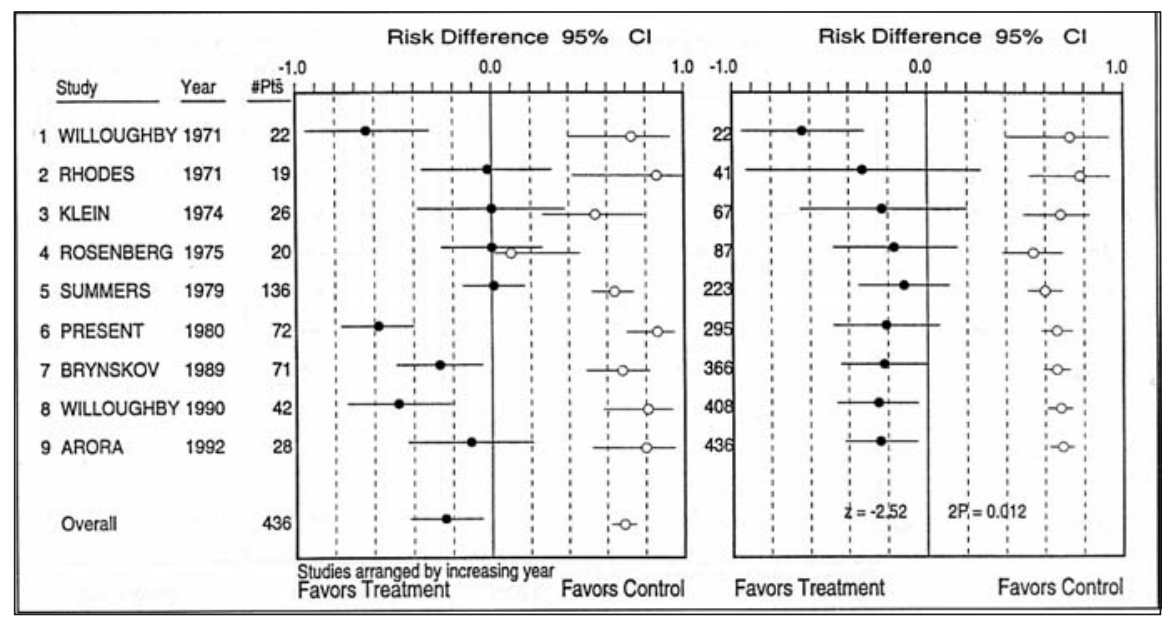

Figure 4) Random effects model (DerSimonian and Laird) showing nine randomized controlled trials of immunosuppressive therapy versus placebo for acute attacks of Crohn's disease. Results are expressed as absolute percentage difference. Studies ordered by year of publication: standard on left and cumulative on right. Odds ratio: under 1.0 favours the immunosuppressive therapy. The horizontal lines are the $95 \%$ CIs around each ratio. The end-point is clinical improvement (response rates). $\mathrm{mRate}$ of failure in placebo-treated groups. References listed in this figure can be obtained in full from the corresponding author. Pts Patients

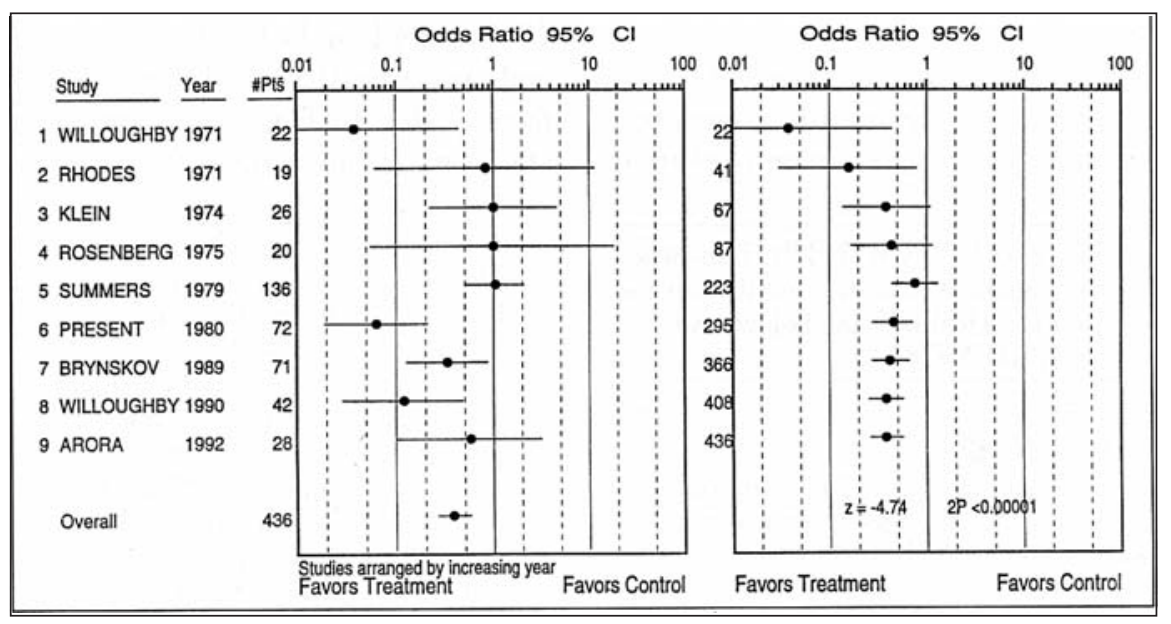

Figure 5) Fixed effects model (Mantel-Haenszel) showing nine randomized controlled trials of immunosuppressive therapy versus placebo for acute attacks of Crohn's disease. Studies ordered by year of publication: standard on left and cumulative on right. Odds ratio: under 1.0 favours the immunosuppressive therapy. The horizontal lines are the $95 \% \mathrm{CI}$ around each ratio. The end-point is clinical improvement (response rates). Note on the right that significance at the $\mathrm{P}<0.05$ level is achieved by 1980 instead of in 1989 as in the random effects model. References listed in this figure can be obtained in full from the corresponding author. Pts Patients

tients to placebo, but the other questions must be answered and the only ethical way to accomplish this is to employ the seemingly best regimen as the control thereafter. This requires a larger number of acute Crohn's disease patients because of the smaller differences being sought, but that should not be difficult. The optimal duration of therapy can be determined by randomizing the stopping time earlier versus later depending on the extent of the response.

Figures 3 to 6 reveal various statisti$\mathrm{cal}$ approaches to pooling the data in the nine RCTs. Figures 3 and 4 illustrate the advantages of employing both the fixed and random effects models. The results of the trials are heterogeneous $(\mathrm{P}<0.01)$ and the cumulative metaanalyses best illustrate the differences resulting from widening the confidence 


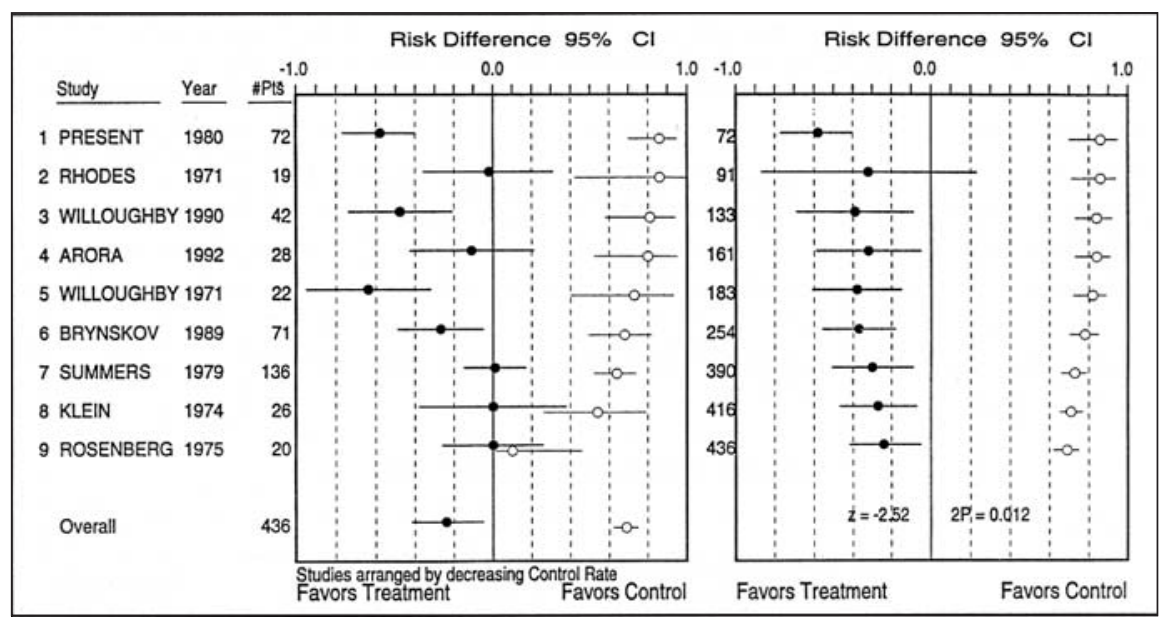

Figure 6) Random effects model (DerSimonian and Laird) showing nine randomized controlled trials of immunosuppressive therapy versus placebo for acute attacks of Crohn's disease. Results are expressed as absolute percentage difference. Studies are arranged in descending order according to the rate of failure in the control group. OOdds ratio: under 1.0 favours the immunosuppressive therapy. The horizontal lines are the $95 \%$ CIs around each ratio. The end-point is clinical improvement (response rates). mRate of failure in placebo-treated groups. References listed in this figure can be obtained in full from the corresponding author. Pts Patients

intervals with the random effects model. The reduction in the odds ratios is statistically significant (confidence intervals no longer crossing one) from

ACKNOWLEDGEMENTS: This study was supported in part by a grant from the Agency for Health Care Policy and Research, R01HS07782.

\section{REFERENCES}

1. Chalmers TC, Lau J. Meta-analytic stimulus for changes in clinical trials. Stat Meth Med Res 1993;2:161-72.

2. Whiting GW, Lau J, Kupelnick B, Chalmers TC. Trends in inflammatory bowel disease: a meta-analytic approach. In: Sutherland LR, Collins SM, Martin F, et al, eds. Inflammatory
1980 onwards in the fixed effects model and only after 1989 in the random effects model. In Figure 5 the random effects model units are different; absolute

Bowel Disease: Basic Research, Clinical Implications and Trends in Therapy. Dordrecht: Kluwer Academic Publishers, 1994:203-17.

3. Chalmers TC, Smith H Jr, Blackburn $\mathrm{B}$, et al. A method for assessing the quality of a randomized control trial. Controlled Clin Trials 1981;2:31-49.

4. Lewis RJ, Wears RL. An introduction to the Bayesian analysis of clinical trials. Ann Emerg Med 1993;22:1328-35.

5. Morris RD, Lau J, Arena NJ, Nardine FE, Chalmers TC. A clinical trials database as a research tool in health care. Online J Curr Clin Trials percentage change and the varying control rates of failure are shown. In Figure 6 the order of the trials was changed from ascending year to descending control rate to illustrate something we have found almost universally in meta-analyses: a direct correlation between response rate and the rate of events in the control group (unpublished data).

The above procedures are new and may be somewhat disturbing to both gastroenterologists and biostatisticians, and considerable thought and dialogue are indicated. But such are the consequences of the very large number of trials of Crohn's disease treatment. The situation actually would be more acute were clinicians to randomize the 'first patient' (6-9), as they should as long as the optimal treatment of the acute disease has not been discovered. That is not likely to occur unless the exact etiology is known, and a large number of patients will have to have presented themselves for treatment before that happens.

1992;1992(Doc No 14):3,293 words;48 paragraphs.

6. Chalmers TC. When should randomization begin? Lancet 1968;i:858. (Lett)

7. Chalmers TC. Randomization of the first patient. Med Clin North Am 1975;59:1035-8.

8. Chalmers TC. The need for early randomization in the development of new drugs for AIDS. J Acquir Immune Defic Syndr 1990;3(Suppl 2): S10-5.

9. Chalmers TC. Randomize the first patient! N Engl J Med 1977;296:107. 


\section{APPENDIX 1: References to the 32 randomized controlled trials in the matrix of new trials (Table 2) listed by cell in the matrix}

D5 Riordan AM, Hunter JO, Cowan RE, et al. Treatment of active Crohn's disease by exclusion diet: East Anglican multicentre controlled trial. Lancet 1993;342:1131-4.

C6 Gorard DA, Hunt JB, Payne-James JJ, et al. Initial response and subsequent course of Crohn's disease treated with elemental diet or prednisolone. Gut 1993;34:1198-202.

C6 Gonzalez-Huix F, de Leon R, Fernandez-Banares F, et al. Polymeric enteral diets as primary treatment of active Crohn's disease: a prospective steroid controlled trial. Gut 1993;34:778-82.

A5 Singleton JW, Hanauer SB, Gitnick $\mathrm{GL}$, et al. Mesalamine capsules for the treatment of active Crohn's disease: results of a 16-week trial. Pentasa Crohn's Disease Study Group. Gastroenterology 1993;104:1293-301.

C5 Landi B, Anh TN, Cortot A, et al. Endoscopic monitoring of Crohn's disease treatment: a prospective, randomized clinical trial. The Groupe d'Etudes Therapeutiques des Affections Inflammatoires Digestives. Gastroenterology 1992;102:1647-53.

C6 Sanderson IR, Udeen S, Davies PS, Savage MO, Walker-Smith JA. Remission induced by an elemental diet in small bowel Crohn's disease. Arch Dis Child 1987;61:123-7.

A4 Sutherland LR, Singleton J, Sessions J, et al. Double-blind placebo controlled trial of metronidazole in Crohn's disease. Gut 1991;32:1071-5.

B4 Ursig B, Alm T, Barany F, et al. A comparative study of metronidazole and sulfasalazine for active Crohn's disease: the cooperative Crohn's disease study in Sweden. II. Result. Gastroenterology 1982;83:550-62.

D6 Harries AD, Jones LA, Danis V, et al. Controlled trial of supplemented oral nutrition in Crohn's disease. Lancet 1983;i:887-90.

D6 Park RH, Galloway A, Danesh BJ, Russell RI. Double-blind trial comparing elemental and polymeric diet as primary treatment for active Crohn's disease. Gut 1989;30:A1453-4. (Abst)

Al Brynskov J, Freund L, Rasmussen SN, et al. A placebo-controlled, double-blind, randomized trial of cyclosporine therapy in active chronic Crohn's disease. N Engl J Med 1989;321:845-50.

A5 Bergman L, Krause U. Postoperative treatment with corticosteroids and salazosulphapyridine (Salazopyrin) after radical resection for Crohn's disease. Scand J Gastroenterol 1976;11:651-66.

A8 Brillanti S, Biasco G, Azzaroni D, et al. Pentasa versus sulphasalazine tablets in the treatment of active Crohn's ileocolitis. Scand J Gastroenterol 1989;158 (Suppl):129-30.

D6 Greenberg GR, Fleming CR, Jeejeebhoy KN, Rosenberg IH, Sales D, Tremaine WJ. Controlled trial of bowel rest and nutritional support in the management of Crohn's disease. Gut 1988;29:1309-15.

A3 Rasmussen SN, Lauritsen K, TageJensen $\mathrm{U}$, et al. 5-aminosalicylic acid in the treatment of Crohn's disease. A 16-week double-blind, placebocontrolled, multicentre study with Pentasa. Scand J Gastroenterol 1987;22:877-83.

A1 Arora S, Katkov WN, Cooley J, et al. A double-blind, randomized, placebocontrolled trial of methotrexate in Crohn's disease. Gastroenterology 1992:102:A591. (Abst)

D6 Giaffer MH, North G, Holdsworth CD. Controlled trial of polymeric versus elemental diet in treatment of active Crohn's disease. Lancet 1990;335:81 6-819.

E5 Saverymuttu S, Hodgson HJ, Chadwick VS. Controlled trial comparing prednisolone with an elemental diet plus non-absorbable antibiotics in active Crohn's disease. Gut 1985;26:994-8.

C6 Hunt JB, Payne-James JJ, Palmer KR, et al. A randomized controlled trial of elemental diet and prednisolone as primary therapy in acute exacerbations of Crohn's disease. Gastroenterology 1989;96:A224. (Abst)

A2 Van Hees PA, Van Lier JH, Van Elteren PH, et al. Effect of sulphasalazine in patients with active Crohn's disease: a controlled doubleblind study. Gut 1981;22:404-9.

D5 O'Morain C, Segal AW, Levi AJ. Elemental diet as primary treatment of acute Crohn's disease: a controlled trial. BMJ 1984;288:1859-62.

A3 Griffiths A, Koletzko S, Sylvester F, Marcon M, Sherman P. Slow-release 5 -aminosalicylic acid therapy in children with small intestinal Crohn's disease. J Pediatr Gastroenterol Nutr 1993;17:186-92.

D6 Raouf AH, Hildrey V, Daniel J, et al. Enteral feeding as sole treatment for
Crohn's disease: controlled trial of whole protein vs amino acid based feed and a case study of dietary challenge. Gut 1991;32:702-7.

D6 Rigaud D, Cosnes J, Le Quintrec Y, et al. Controlled trial comparing two types of enteral nutrition in treatment of active Crohn's disease: elemental versus polymeric diet. Gut 1991;32:1492-7.

B9 Rijk MC, van Hogezand RA, van Lier HJ, van Tongeren JH. Sulphasalazine and prednisone compared with sulphasalazine for treating active Crohn's disease. A double-blind, randomized, multicentre trial. Ann Intern Med 1991;114:445-50.

C7 Ewe K, Press AG, Singe CC, et al. Azathioprine combined with prednisolone or monotherapy with prednisolone in active Crohn's disease. Gastroenterology 1993;105:367-72.

E6 Lochs H, Steinhardt HJ, Klaus-Wentz B, et al. Comparison of enteral nutrition and drug treatment in active Crohn's disease. Results of the European Cooperative Crohn's Disease Study. IV. Gastroenterology 1991;101:881-8.

C6 Thomas AG, Taylor F, Miller V. Dietary intake and nutritional treatment in childhood Crohn's disease. J Pediatr Gastroenterol Nutr 1993;17:75-81.

C6 Lindor KD, Fleming CR, Burnes

D7 JU, Nelson JK, Ilstrup DM. A

C7 randomized prospective trial comparing a defined formula diet, corticosteroids and a defined formula diet plus corticosteroids in active Crohn's disease. Mayo Clin Proc 1992;67:328-33.

C7 Afdhal NH, Long A, Lennon J, Crowe J, O'Donoghue DP.

Controlled trial of antimycobacterial therapy in Crohn's disease. Clofazimine versus placebo. Dig Dis Sci 1991;36:449-53.

C5 Brignola C, De Simone G, Iannone $\mathrm{P}$, et al. Influence of steroid treatment's duration in patients with active Crohn's disease. Agents Actions 1992;Spec No:C90-2.

C3 Jenss H, Hartmann F, Scholmerich J, German ASA-Study Group. 5-aminosalicylic acid versus methylprednisolone in the treatment of active Crohn's disease - first results of double-blind clinical trial. Scand J Gastroenterol 1989; 158(Suppl):136. 


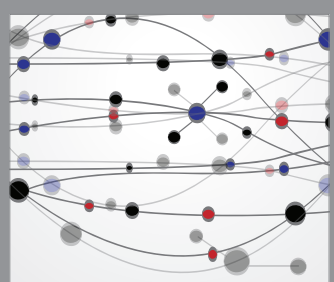

The Scientific World Journal
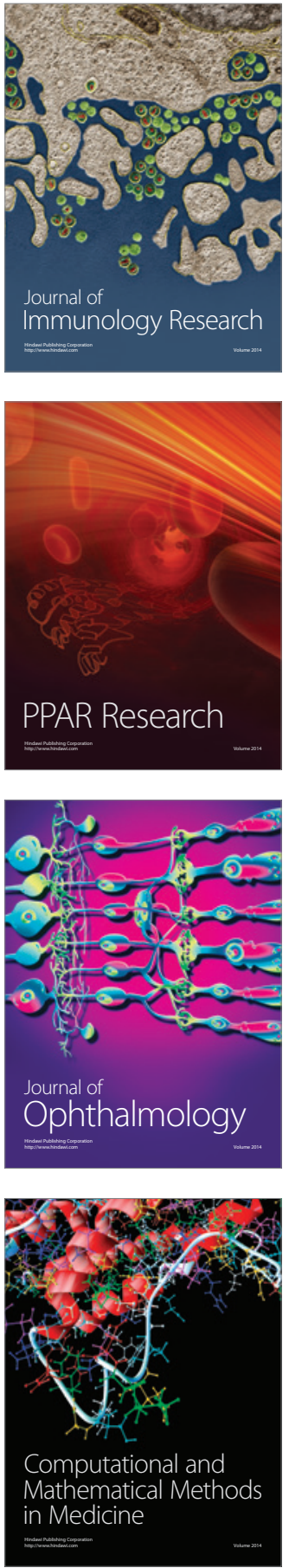

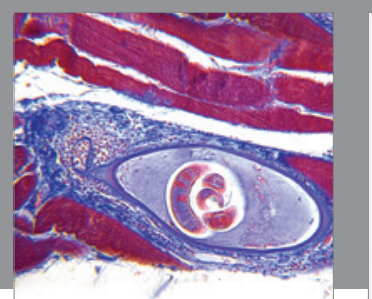

Gastroenterology Research and Practice

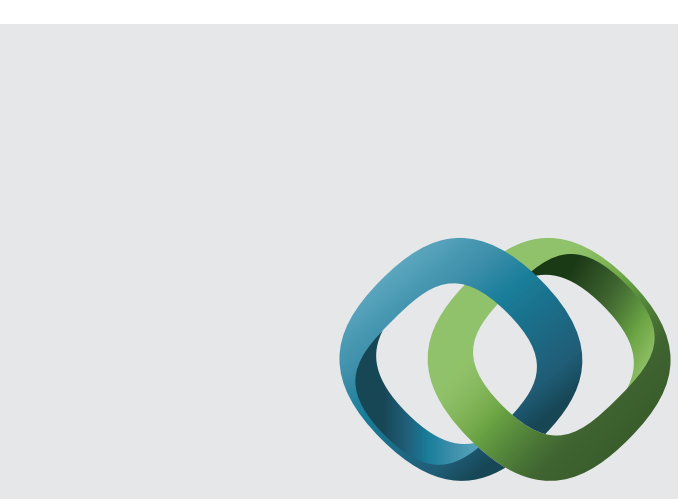

\section{Hindawi}

Submit your manuscripts at

http://www.hindawi.com
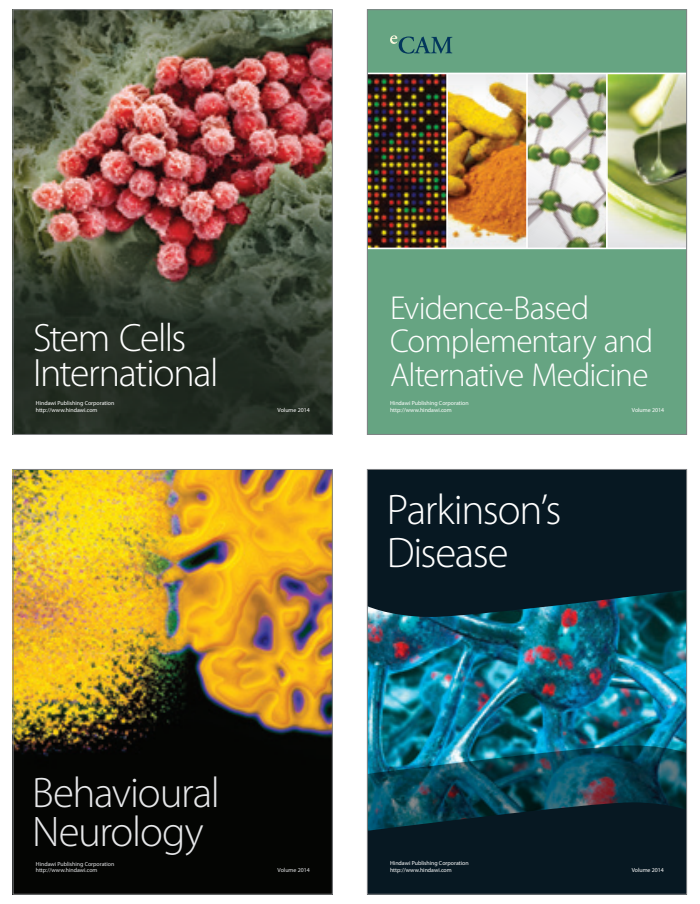
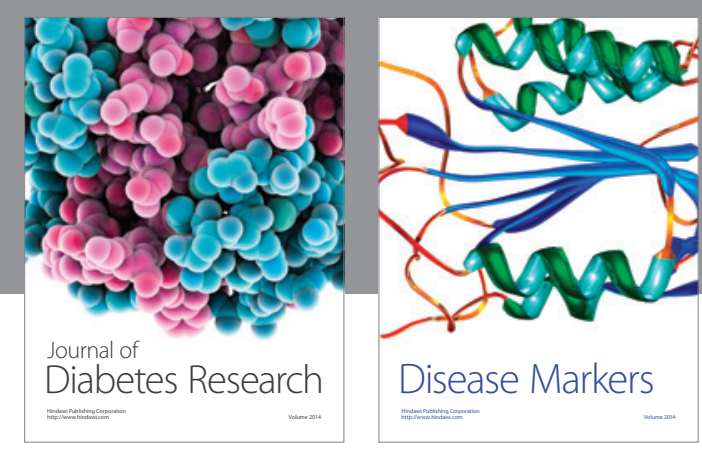

Disease Markers
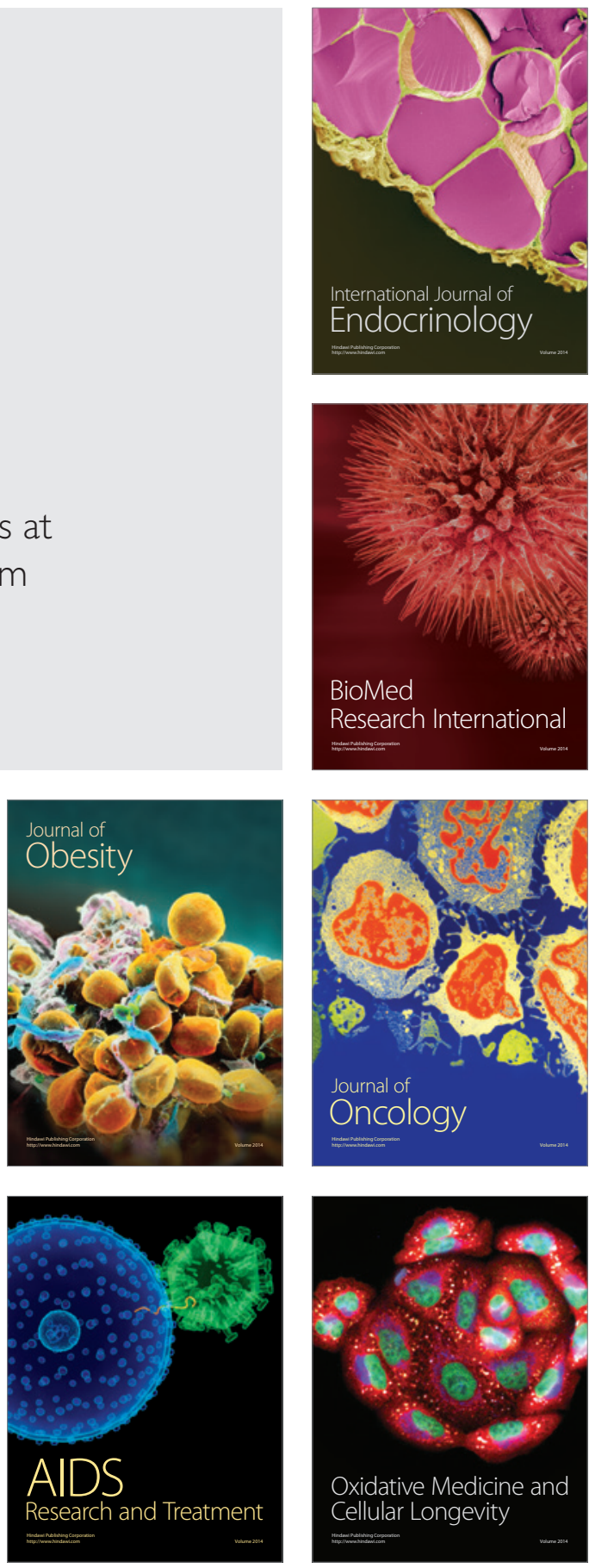